\title{
CULTIVATION OF ARTHROSPIRA (SPIRULINA) PLATENSIS IN DESALINATOR WASTEWATER AND SALINATED SYNTHETIC MEDIUM: PROTEIN CONTENT AND AMINO-ACID PROFILE
}

\author{
Harriet Volkmann $^{1 *}$; Ulisses Imianovsky ${ }^{1}$; Jorge L.B. Oliveira² ${ }^{2}$ Ernani S. Sant'Anna ${ }^{3}$ \\ ${ }^{1}$ Ciência de Alimentos, Universidade de Santa Catarina, Florianópolis, SC, Brasil; ${ }^{2}$ Departamento de Engenharia Rural, \\ Universidade de Santa Catarina, Florianópolis, SC, Brasil; ${ }^{3}$ Departamento de Ciência de Alimentos e Tecnologia, Universidade \\ Federal de Santa Catarina, Florianópolis, SC, Brasil.
}

Submitted: December 20, 2006; Returned to authors for corrections: May 31, 2007; Approved: January 14, 2008.

\begin{abstract}
Arthrospira (Spirulina) platensis was cultivated in laboratory under controlled conditions $\left(30^{\circ} \mathrm{C}\right.$, photoperiod of 12 hours light/dark provided by fluorescent lamps at a light intensity of $140 \mu \mathrm{mol}$ photons. $\mathrm{m}^{-2} \cdot \mathrm{s}^{-1}$ and constant bubbling air) in three different culture media: (1) Paoletti medium (control), (2) Paoletti supplemented with 1 g.L. $\mathrm{L}^{-1} \mathrm{NaCl}$ (salinated water) and (3) Paoletti medium prepared with desalinator wastewater. The effects of these treatments on growth, protein content and amino acid profile were measured. Maximum cell concentrations observed in Paoletti medium, Paoletti supplemented with salinated water or with desalinator wastewater were $2.587,3.545$ and $4.954 \mathrm{~g} . \mathrm{L}^{-1}$, respectively. Biomass in medium 3 presented the highest protein content $(56.17 \%$ ), while biomass in medium 2 presented $48.59 \%$ protein. All essential amino acids, except lysine and tryptophan, were found in concentrations higher than those requiried by FAO.
\end{abstract}

Key words: Arthrospira platensis, desalinator wastewater, aminogram.

\section{INTRODUCTION}

Cyanobacterium Arthrospira (Spirulina) platensis is commercial product with high nutritional value, serving as a source of nutrients for food, chemical and pharmaceutical industry $(9,10,19,20)$. It is the major known source of vitamin $\mathrm{B}_{12}$, having high protein content (6). It presents immunepromoting effects, such as enhancement of macrophage function and in vitro and in vivo antioxidant activity (19). Due to lack of cellulose in its cell wall, $85-95 \%$ is assimilated by the organism (2). It is also used in aquaculture as feed in fish, crustacean, shellfish and bivalve cultures (9). Also, it is applied in wastewater treatment and agriculture $(9,10)$. Arthrospira platensis is naturally found in tropical regions inhabiting alkaline lakes ( $\mathrm{pH} 11$ ) with high concentration of $\mathrm{NaCl}$ and bicarbonates $(4,13,14,17)$. These limiting conditions for other microorganisms allow cultivation of this microalga in opened reactors (10).

In the Northeast of Brazil, a semi-arid area of $900,000 \mathrm{Km}^{2}$ is also known as Polygon of Drought. This area corresponds approximately to the isoyhets (lines of equal precipitation) of
$800 \mathrm{~mm}$ of annual rainfall. Attempting to reduce the drought problem in the area and set up alternatives, Brazilian government is encouraging the captation of ground water. However, reservoirs from this region present high levels of salinity, making the use of desalinators mandatory. Nevertheless, these processes generate residues with high saline concentration with great environmental impact. The aim of this work was to cultivate Arthrospira platensis in this wastewater and in salinated synthetic medium, evaluating the amino acid profile and the protein content of the cells.

\section{MATERIALS AND METHODS}

\section{Microorganism}

Arthrospira platensis strain used in this work was given by the Laboratório de Bioquímica from the Departamento de Química of the Fundação Universidade Federal do Rio Grande - FURG/RS, Brazil. The strain was kept in Paoletti medium according to Ferraz et al. (7), with modifications, presenting the following composition (g.L $\left.{ }^{-1}\right): 0.92 \mathrm{NaCl} ; 1.88 \mathrm{Na}_{2} \mathrm{SO}_{4} ; 0.50$

*Corresponding Author. Mailing address: Rod. Admar Gonzaga 1346, CEP 88034-001, Itacorubi, Florianópolis, Santa Catarina, Brasil. E-mail: harriet.bnu@terra.com.br 
$\mathrm{K}_{2} \mathrm{HPO}_{4} ; 8.89 \mathrm{Na}_{2} \mathrm{CO}_{3} ; 15.15 \mathrm{NaHCO}_{3} ; 0.05 \mathrm{CaCl}_{2} .2 \mathrm{H}_{2} \mathrm{O} ; 2.57$ $\mathrm{KNO}_{3} ; 0.25 \mathrm{MgSO}_{4} .7 \mathrm{H}_{2} \mathrm{O} ; 1.0 \mathrm{~mL} . \mathrm{L}^{-1}$ of micronutrient solution $\left(2.86 \mathrm{H}_{3} \mathrm{BO}_{3} ; 1.54 \mathrm{MnSO}_{4} . \mathrm{H}_{2} \mathrm{O} ; 0.22 \mathrm{ZnSO}_{4} .7 \mathrm{H}_{2} \mathrm{O} ; 0.39\right.$ $\mathrm{NaMoO}_{4} .2 \mathrm{H}_{2} \mathrm{O} ; 0.079 \mathrm{CuSO}_{4} .5 \mathrm{H}_{2} \mathrm{O}$ and $\left.0.038 \mathrm{CoCl}_{2} .6 \mathrm{H}_{2} \mathrm{O}\right)$ and $1,0 \mathrm{~mL} \cdot \mathrm{L}^{-1} \mathrm{Fe}$-EDTA solution (29.8 EDTA-Na 2 ; $24.9 \mathrm{FeSO}_{4} \cdot 7 \mathrm{H}_{2} \mathrm{O}$ ).

\section{Culture media}

Three different media were prepared for cultivation of $A$. platensis. Paoletti medium was used as control medium. Salinated water, the second medium, was produced by adding $1 \mathrm{~g} . \mathrm{L}^{-1}$ $\mathrm{NaCl}$ to Paoletti medium. The third medium (dessalinator wasterwater) was a modified Paoletti medium in which distilled water was replaced by desalinator wastewater and the concentration of the components of Paoletti medium was reduced by $50 \%$. This medium was produced as follows: the components were solubilized in wastewater, centrifuged at 4,000 rpm for $15 \mathrm{~min}$ and the precipitate discarded. Desalinator wastewater was given by the Laboratório de Referência em Dessalinização, Campina Grande/PB, Brazil, and presented the following composition, determined according to United States Environmental Protection Agency $\left(\mathrm{mg} . \mathrm{L}^{-1}\right)$ : Bicarbonate 0.00; Calcium 585.00; Carbonates 38.10; Chloride 4,340.04; Phosphate $<0.05$; Magnesium 433.00; Nitrate 779.27; Potassium 101.50; Sodium 1245.00 and Sulfate 919.65. The $\mathrm{pH}$ of the three media was adjusted to $9.4 \pm 0.2$. The experiments were done in triplicate.

\section{Inoculum preparation}

Previous inocula of $A$. platensis were prepared for three media. Microalgae were cultivated in $4 \mathrm{~L}$ Erlenmeyer flasks, with photoperiod of 12 hours light/dark provided by fluorescent lamps at a light intensity of $140 \mu \mathrm{mol}$ photons. $\mathrm{m}^{-2} \cdot \mathrm{s}^{-1}$ and temperature of $30 \pm 1^{\circ} \mathrm{C}$. Experiments were initiated with $10 \%$ (v/ v) of inoculum. Media agitation was carried out by bubbling air.

\section{Growth evaluation}

Cell concentration was estimated at 72 hours intervals using a calibration curve $(560 \mathrm{~nm})$ for each medium. Experiments finished when decreasing of cell growth was observed. At the end of cultivation, biomass was filtered $(0.45 \mu \mathrm{m}$ cellulose acetate filter), lyophilized and stored at $-20^{\circ} \mathrm{C}$. Cell productivity was also determined.

\section{pH determination}

$\mathrm{pH}$ of the media was measured at each 72 hours using a potentiometer.

\section{Protein content and aminogram}

Total protein content in the lyophilized biomass was determined by the Kjehldahl method (1). Amino acid profile was carried out according to White et al. (18) and determination of tryptophan was performed according to Spies (16) using HPLC technique.

\section{Statistical analysis}

Results of the analyses were submitted to analysis of variance (ANOVA) with confidence level of $95 \%(p<0.05)$ in order to verify significant differences among media. Statistical analyses were carried out using Statistica ${ }^{\circledR} 6.0$ software.

\section{RESULTS AND DISCUSSION}

\section{Effect of culture medium in growth}

Fig. 1 shows the growth of Arthrospira platensis in the three tested culture media. Despite having started with a similar initial inoculum, after 9 days of cultivation, the growth on desalinator wastewater was more intense than in the other two media. The difference became more evident on day 23, where cell concentration reached $4.954 \mathrm{~g}$. $\mathrm{L}^{-1}$ which is $91.5 \%$ higher than that observed in Paoletti medium. An intermediate production of biomass was observed for microalgae cultivated in salinated water, which presented increased growth from day $15 \mathrm{on}$, reaching a final cell concentration of $3.545 \mathrm{~g} . \mathrm{L}^{-1}$ which is $37.03 \%$ higher than that in Paoletti medium. Regarding to Paoletti medium, the values for maximum cell concentration obtained are close to those reported by Oliveira et al. (9), 2.4 g.L $\mathrm{L}^{-1}$, but lower than values reported by Rafiqul et al. (13), who used Zarrouk medium and reached $2.7 \mathrm{~g} . \mathrm{L}^{-1}$ at day 20 . However, values attained were $49.0 \%$ higher than those reported by Pelizer et al. (11) $(1.3$ g.L.-1).

ANOVA tests indicated that the differences observed between treatments were significant $(p=0.008722)$. Yet, the differences observed in final cell concentration in salinated water and Paoletti medium were not significant, nor were those observed in salinated water and desalinator wastewater. However, the difference in cell concentratrion in Paoletti medium

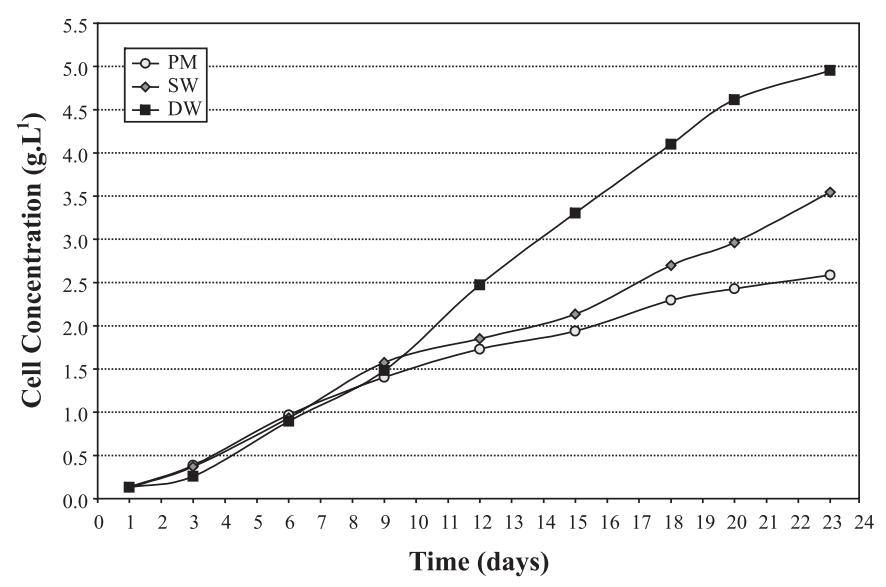

Figure 1. Cell concentration of Arthrospira platensis in different culture media (PM - Paoletti medium; SW - salinated water and DW - desalinator wastewater). 
and desalinator wastewater was significant. Microalgae cultived in Paoletti medium, salinated water and desalinator wastewater presented cell productivities of 0.109 g.. $\mathrm{L}^{-1}$.day ${ }^{-1}, 0.150$ g.L.- day $^{-1}$ and $0.210 \mathrm{~g} . \mathrm{L}^{-1}$.day ${ }^{-1}$, respectively. It is possible to note that the cell productivities of desalinator wastewater was higher (92.9\%) than Paoletti medium. $\mathrm{pH}$ values ranged from 9.6 to 10.5 for Paoletti medium, from 9.6 to 10.6 for salinated water and from 9.4 to 10.2 for desalinator wastewater.

\section{Effect of culture medium on protein and amino acid content}

A. platensis cultivated in salinated water presented a total protein content of $48.59 \%$ in dry weight, while in desalinator wastewater the content was $56.17 \%$. The differences between these results were significant $(\mathrm{p}=0.001661)$. Similar values for total protein, ranging from $46 \%$ to $50 \%$ in dry weight, were reported by Richmond (13) in A. platensis, but the values in desalinator wastewater were lower than that presented by Oliveira et al. (9). Pelizer et al. (11), studying different initial inocula, reported 55.0 - 61.0\% protein content. Similar values were found by Rafiqul et al. (12), who found $58.6 \%$ of total protein content when using Zarrouk medium. Zeng and Vonshak (20) reported that cells under stress conditions, including salinity-stress, have a lower protein synthesis capacity. This fact can probably explain lower protein contents found in biomasses grown in salinated water and desalinator wastewater. Besides, an alternative for salinity-stress adaptation is the increase in carbohydrates metabolism (20).

Among analyzed amino acids, four were responsible for $39.33 \%$ (desalinator wastewater) and $40.34 \%$ (salinated water) of the total amino acid content (Table 1). Regarding to desalinator wastewater, the main amino acids were: leucine, alanine, glutamine and histidine. Concerning salinated water, the main amino acids were: leucine, asparagine, glutamine e histidine. Tryptophan was the amino acid found in lowest content: 0.082 and $0.060 \mathrm{~g} / 100 \mathrm{~g}$ of protein in desalinator wastewater and salinated water, respectively.

The contents of all amino acids were higher than those reported by Grinstead et al. (8), except tryptophan $(0.6 \%)$ and cysteine $(0.7 \%)$. As can be observed in Table $1,57.60 \%$ of the amino acids in biomass grown in desalinator wastewater were essential amino acids. In biomass grown in salinated water this content was of $52.10 \%$. Values obtained for biomass grown in desalinator wastewater are close to those reported by Babadzhanov et al. (2), who observed that the contend of essential amino acids in A. platensis biomass was around $60 \%$.

As shown in Table 1, the essential amino acid content were above the minimum values required by FAO (16) with histidine overcoming in $483 \%$ (biomass grown in salinated water) and $548 \%$ (biomass grown in desalinator wastewater) the FAO's requirements. However, lysine and tryptophan did not reach the minimum requirements: lysine supplied $76 \%$ (salinated
Table 1. Total amino acids of Arthrospira platensis (g/100 $\mathrm{g}$ of protein)

\begin{tabular}{lcccc}
\hline Amino Acids & Richmond $^{\mathrm{a}}$ & $\begin{array}{c}\text { Salinated } \\
\text { Water }\end{array}$ & $\begin{array}{c}\text { Desalinator } \\
\text { Wastewater }\end{array}$ & $\begin{array}{c}\mathrm{FAO} / \\
\mathrm{WHO}^{\mathrm{b}}\end{array}$ \\
\hline Isoleucine* & 6.70 & 5.71 & 6.49 & 2.80 \\
Leucine* & 9.80 & 9.26 & 10.17 & 6.60 \\
Valine & 7.10 & 6.45 & 6.54 & 3.50 \\
Lysine* & 4.80 & 4.42 & 4.99 & 5.80 \\
Phenylalanine* & 5.30 & 4.45 & 5.16 & 6.30 \\
Tyrosine & 5.30 & 5.26 & 5.69 & \\
Methionine* & 2.50 & 2.05 & 2.16 & 2.50 \\
Cysteine & 0.90 & 0.59 & 0.57 & \\
Tryptophan & 0.30 & 0.06 & 0.08 & 1.10 \\
Threonine* & 6.20 & 4.65 & 5.31 & 3.40 \\
Histidine* & 2.20 & 9.17 & 10.41 & 1.90 \\
Alanine* & 9.50 & 8.51 & 9.27 & \\
Arginine* & 7.30 & 7.09 & 8.00 & \\
Asparagine* & 11.80 & 9.86 & 3.90 & \\
Glutamine* & 10.30 & 13.40 & 9.47 & \\
Glycine* & 5.70 & 1.10 & 2.98 & \\
Proline* & 4.20 & 3.33 & 3.75 & \\
Serine* & 5.10 & 4.59 & 5.00 & \\
a - Richmond (15); & \multicolumn{5}{l}{} \\
b-Recommendation for children of 2-5 years old, according to FAO/ \\
WHO (apud 16); \\
*significant differences were observed between the treatments salinated \\
water and desalinator wastewater (p<0.05). \\
\end{tabular}

water) and $86 \%$ (desalinator wastewater) of FAO's requeriments, while tryptophan supplied only $5.45 \%$ (salinated water) and $7.45 \%$ (desalinator water). These results are in disagreement with data presented by Danesi et al. (5) who reported that, among all amino acids of A. platensis, only methionine content was below the FAO's minimum requirements.

It is important to notice that according to Campanella et al. (3) tryptophan levels in A. platensis are usually not hight, with contents ranging from $0.139-0.144 \mathrm{~g} / 100 \mathrm{~g}$ of protein.

Regarding to amino acids profile, biomass from salinated water presented higher content of non essential amino acids, such as asparagine and glutamine. However, the difference in contents of valine, tyrosine, cysteine and tryptophan in the two types of biomass was not significant.

According to these data, cultivation of A. platensis in desalinator wastewater produces high levels of biomass (4.954 g. $\left.\mathrm{L}^{-1}\right)$. However, the produced biomass contains only two essential amino acids, lysine and tryptophan, both below FAO's minimum requirements. Thus, cultivation of A. platensis in this medium is possible but more studies are necessary in order to better evaluate the application in large scale production. 


\section{ACKNOWLEDGMENTS}

To Dr. Kepler Borges França, from Universidade Federal de Campina Grande, Laboratório de Referência em Dessalinização by supplying desalinator wastewater.

\section{RESUMO}

\section{Cultivo de Arthrospira (Spirulina) platensis em rejeito de dessalinizador e meio sintético salinizado: teor protéico e perfil de aminoácidos}

Arthrospira (Spirulina) platensis foi cultivada em laboratório sob condições controladas $\left(30^{\circ} \mathrm{C}\right.$, intensidade luminosa de $140 \mu \mathrm{mol}$ fótons. $\mathrm{m}^{-2} . \mathrm{s}^{-1}, 12$ horas claro/escuro e insuflação constante de ar atmosférico), em três meios de cultivo: (1) meio de Paoletti (controle), (2) meio de Paoletti suplementado com 1,0 g.L. $\mathrm{L}^{-1}$ de $\mathrm{NaCl}$ (água salinizada) e (3) meio de Paoletti preparado com rejeito de dessalinizador. Foi verificado o efeito destes tratamentos no crescimento, teor de proteínas e aminoácidos. As concentrações celulares máximas obtidas foram de 2,587; 3,545 e 4,954 g.L.-1 no meio controle, meio de Paoletti suplementado com água salinizada ou com rejeito de dessalinizador, respectivamente. Com relação às concentrações protéicas, estas foram maiores na biomassa cultivada no meio 3 , com $56,17 \%$, enquanto que a biomassa cultivada no meio 2 apresentou $48,59 \%$. A maioria dos aminoácidos essenciais encontrou-se acima dos limites requeridos pela FAO, com exceção apenas de lisina e triptofano.

Palavras-chave: Arthrospira platensis, rejeito de dessalinizador, aminograma

\section{REFERENCES}

1. AOAC. (1990). Official methods of analysis of the Association of Official Analytical Chemists. AOAC, Washington, D.C.

2. Babadzhanov, A.S.; Abdusamatova, N.; Yusupova, F.M.; Faizullaeva, N.; Mezhlumyan, L.G.; Malikova, M.K. (2004). Chemical composition of Spirulina platensis cultivated in Uzbekistan. Chem. Nat. Compd., 40(3), 276-279.

3. Campanella, L.; Crescentini, G.; Avino, P. (1999). Simultaneous determination of cysteine, cystine and 18 other amino acids in various matrices by high-performance liquid chromatography. $J$. Chromatogr. A., 833, 137-145.

4. Cozza, K.L.; Costa, J.A.V. (2000). Lipídios em Spirulina. Vetor Rev. Cienc. Exatas Eng., 10, 69-80.

5. Danesi, E.D.G.; Rangel-Yagui, C.O.; Carvalho, J.C.M.; Sato, S. (2002). An investigation of effect of replacing nitrate by urea in the growth and production of chlorophyll by Spirulina platensis. Biomass Bioenergy, 23, 261-269.

6. Estrada, J.E.P.; Bescós, P.B.; Fresno, A.M.V. (2001). Antioxidant activity of different fractions of Spirulina platensis protean extract. Il Farmaco., 56, 497-500.

7. Ferraz, C.A.M.; Aquarone, E.; Krauter, M. (1985). Efeito da luz e do pH no crescimento de Spirulina maxima. Rev. Microbiol., 16(2), 132-137.

8. Grinstead, G.S.; Tokach, M.D.; Dritz, S.S.; Goodband, R.D.; Nelssen, J.L. (2000). Effects of Spirulina platensis on growth performance of weanling pigs. Anim. Feed Sci. Technol., 83, 237-247.

9. Oliveira, M.A.C.L.; Monteiro, M.P.C.; Robbs, P.G.; Leite, S.G.F. (1999). Growth and chemical composition of Spirulina maxima and Spirulina platensis biomass at different temperatures. Aquac. Int., 7, 261-275.

10. Pelizer, L.H. (2002). Spirulina platensis growth estimation by $\mathrm{pH}$ determination at different cultivations conditions. EJB Electron. J. Biotechnol., 5(3), 251-257.

11. Pelizer, L.H.; Danesi, E.D.G.A.; Rangel, C.O.A.; Sassano, C.E.N.; Carvalho, J.C.M.; Sato, S.; Moraes, I.O. (2003). Influence of inoculum age and concentration in Spirulina platensis cultivation. J. Food Eng., 56, 371-375.

12. Rafiqul, I.M.; Jalal, K.C.A.; Alam, M.Z. (2005). Environmental factors for optimisation of Spirulina biomass in laboratory culture. Biotechnology, 4(1), 19-22.

13. Richmond, A. (1990). Handbook of microalgal mass culture. CRC Press, Boston.

14. Richmond, A. (2004). Handbook of microalgal culture biotechnology and applied phycology. Blackwell Science, Oxford.

15. Roman, J.A.; Sgarbieri, V.C. (2005). Obtenção e caracterização química e nutricional de diferentes concentrados de caseína. Rev. Nutr., 18(1), 75-83.

16. Spies, J.R. (1967). Determination of tryptophan in proteins. Anal. Chem., 39(12), 1412-1416.

17. Vonshak, A. (1996). Spirulina platensis (Arthrospira) - physiology, cell biology and biotechnology. Taylor \& Francis, Londres.

18. White, J.A.; Hart, R.J.; Kry, J.C. (1986). An evaluation of the Waters Pico-Tag system for the amino acid analysis of food materials. $J$. Autom. Chem., 8, 170-177.

19. Xue, C.; Hu, Y.; Saito, H.; Zhang, Z.; Li, Z.; Cai, Y.; Ou, C.; Lin, H.; Imbs, A.B. (2002). Molecular species composition of glycolipids from Sprirulina platensis. Food Chem., 77, 9-13.

20. Zeng, M.T.; Vonshak, A. (1998). Adaptation of Spirulina platensis to salinity-stress. Comp. Biochem. Physiol. Part A Mol. Integr. Physiol., 120, 113-118. 